\title{
Gerakan Literasi Finansial di SMA Kabupaten Kubu Raya Kalimantan Barat
}

\author{
Heni Kuswanti ${ }^{*}$, Maria Ulfah² \\ 1,2Universitas Tanjungpura, Pontianak - Indonesia
}

\section{A R T I C L E I N F O}

Article history:

Received February, 26

2021

Received in revised form

May, 282021

Accepted June, 42021

Available online June, 28

2021

\section{Kata Kunci: \\ gerakan literasi finansial, \\ Literasi finansial. \\ Keywords: \\ Financial literacy, financial \\ literacy movement.}

A B S T R A K

Tujuan penelitian ini untuk mengetahui bagaimana gerakan literasi finansial dengan indikator basis kelas, basis budaya sekolah dan basis masyarakat di SMA Kabupaten Kubu Raya Kalimantan Barat. Metode yang digunakan adalah metode deskriptif dengan bentuk survei. Subjek penelitian adalah guru ekonomi, pengumpulan data dilakukan dengan wawancara dan daftar isian menggunakan google form. Langkah analisis data menggunakan Analysis Interactive Model dari Miles dan Huberman. Teknik pemeriksaan keabsahan data dengan triangulasi sumber, triangulasi teknik, dan perpanjangan partisipan. Hasil penelitian menunjukkan bahwa belum terdapat gerakan literasi finansial di SMA Kabupaten Kubu Raya Kalimantan Barat. Pada indikator basis sekolah belum pernah dilakukan pelatihan literasi finansial dan belum ada penerapan nilai literasi finansial dalam pembelajaran. Pada indikator basis budaya sekolah belum tersedia variasi buku dan alat peraga literasi finansial, frekuensi peminjaman bahan bacaan literasi finansial hanya sebatas peminjaman buku paket ekonomi di perpustakaan, belum ada kegiatan dan kebijakan literasi finansial, penyajian informasi literasi finansial hanya pada mata pelajaran ekonomi saja, belum terdapat situs yang berhubungan dengan literasi finansial, belum terdapat bank sekolah sementara koperasi sekolah hanya sebagian kecil yang aktif. Pada indikator basis masyarakat belum terdapat alat dan media pendukung literasi finansial dan belum ada keterlibatan orang tua dan masyarakat dalam mengembangkan literasi finansial.

\section{A B S T R A C T}

The purpose of this study was to determine how the financial literacy movement with indicators of class basis, school cultural basis and community basis in Senior High School Kubu Raya Regency, West Kalimantan. The method used was a descriptive method with a survey form. The research subject was an economic teacher, data collection was done by interview and a questionnaire using google form. The data analysis step used the Interactive Analysis Model from Miles and Huberman. The technique of checking the validity of the data used source triangulation, technique triangulation, and participant extension. The results showed that there was no financial literacy movement in Senior High School Kubu Raya, West Kalimantan. In the school-based indicator there has never been any financial literacy training and there has been no application of the value of financial literacy in learning. On the school cultural basis indicator, there were no variations in books and financial literacy props, the frequency of borrowing financial literacy reading materials is limited to borrowing economic textbooks in the library, there were no financial literacy activities and policies, the presentation of financial literacy information was only on economic subjects, there were no sites related to financial literacy, there were no school bank while only a small number of school cooperations are active. In the community-based indicator, there were no supporting tools and media for financial literacy and there was no involvement of parents and the community in developing financial literacy.

Copyright (C) Ekuitas: Jurnal Pendidikan Ekonomi. All rights reserved.

\footnotetext{
* Corresponding author.

E-mail : heni.kuswanti@fkip.untan.ac.id (Heni Kuswanti)
} 


\section{Pendahuluan}

Indonesia adalah negara dengan kepemilikan sumber daya alam yang berlimpah dan jumlah sumber daya manusia yang tinggi. Ketersediaan sumber daya tersebut merupakan modal untuk dapat mewujudkan Indonesia menjadi negara maju yang mampu bersaing dengan negara lain. Abad 21 saat ini menuntut manusia agar memiliki kecakapan hidup yang lebih maju dari abad sebelumnya, pada tahun 2015 forum ekonomi dunia telah menyepakati agar dapat memiliki kecakapan hidup abad ke-21 salah satunya adalah mempunyai penguasaan literasi finansial.

Literasi adalah kemampuan berbahasa seseorang dalam menyimak, berbicara, membaca, dan menulis untuk dapat melakukan komunikasi dengan berbagai cara sesuai dengan tujuan yang yang hendak dicapai (Sari \& Pujiono, 2017). Literasi saat ini merupakan kemampuan yang sangat penting sebagai upaya peningkatan kualitas manusia, tuntutan literasi yang mampu dipenuhi akan meningkatkan kompetensi dan berpengaruh positif pada produktivitas. Literasi finansial merupakan pengetahuan dan keterampilan untuk dapat mengimplementasikan pengetahuan mengenai filosofi dan risiko, keterampilan dalam menetapkan keputusan bidang keuangan sehingga dapat meningkatkan kesejahteraan keuangan pribadi maupun berpartisipasi aktif di lingkungan masyarakat (Fianto et al., 2017).

Pertumbuhan sektor ekonomi nasional sangat ditentukan oleh tingkat literasi finansial masyarakat. Masyarakat yang melek keuangan mempunyai pengetahuan tentang berbagai macam produk dan pelayanan jasa keuangan yang ditawarkan sehingga mampu menentukan produk dan jasa secara optimal dengan dapat mempertimbangkan faktor resiko keuangan yang ada. Literasi keuangan juga dikaitkan dengan perolehan keuntungan yang lebih tinggi pada investasi aset yang lebih kompleks seperti saham yang biasanya menawarkan tingkat pengembalian yang lebih tinggi (Lusardi et al., 2017).

Pemerintah pada tahun 2016 melalui Kementerian Pendidikan dan Kebudayaan telah membangun budaya literasi untuk setiap ranah lingkungan yaitu lingkungan keluarga, lingkungan sekolah, dan lingkungan masyarakat. Kemendikbud menggalakkan Gerakan Literasi Nasional (GLN) sebagai bentuk penerapakan Peraturan Menteri Pendidikan dan Kebudayaan Nomor 23 Tahun 2015 tentang Penumbuhan Budi Pekerti.

Otoritas Jasa Keuangan (OJK) pada tahun 2016 melakukan Survei Nasional Literasi dan Inklusi Keuangan (SNLIK), survei akses terhadap literasi keuangan secara komposit sebesar 23,4 \% saja. Hal ini menujukkan bahwa pemahaman (literasi) keuangan untuk kalangan pelajar dan mahasiswa masih cukup rendah. Sekolah merupakan Lembaga Pendidikan formal yang memberikan berbagai pengajaran dan pengalaman bagi peserta didik. Sekolah memiliki fungsi untuk dapat membentuk peserta didik agar memiliki pemahaman, keahlian dan sikap sesuai dengan tujuan pendidikan nasional. Kurikulum setiap mata pelajaran dibuat dengan tujuan tertentu, pelaksanaan pembelajaran dilakukan dengan metode dan materi yang digunakan guru dengan tujuan mencapai tujuan setiap pelaksanaan pembelajaran.

Survei Nasional Literasi dan Inklusi Keuangan (SNLIK) yang juga dilakukan oleh Otoritas Jasa Keuangan (OJK) pada tahun pada tahun 2019 dengan hasil indeks literasi keuangan mencapai 38,03\%. Berdasarkan hasil survei tersebut diperoleh informasi bahwa baru sekitar 38 dari 100 orang yang memiliki pengetahuan, keterampilan, dan kepercayaan dengan kategori memadai (well literate). Hasil survei ini menunjukkan bahwa belum sepenuhnya masyarakat indonesia memiliki pengetahuan tentang lembaga keuangan yang ada, produk keuangan dan pelayanan jasa keuangan yang ditawarkan, serta keterampilan untuk mengetahui karakteristik, keuntungan, risiko, hak dan kewajiban atas produk dan pelayanan jasa keuangan.

Sekolah merupakan lembaga yang tepat untuk membangun literasi finansial bagi siswa, karena pendidikan merupakan investasi jangka panjang yang akan menentukan kualitas sumber daya manusia yang akan memberikan dampak pada pembagunan nasional. Literasi keuangan mempengaruhi segala sesuatu mulai dari keputusan keuangan sehari-hari hingga jangka panjang, dan ini terjadi implikasi bagi individu dan masyarakat (Lusardi, 2019). Remund (2010) dalam penelitiannya menyatakan bahwa konsep literasi finansial terdiri dari lima bagian yaitu : (1) pemahaman mengenai konsep finansial, (2) kemahiran melakukan komunikasi tentang konsep finansial, (3) kemampuan pengelolaan finansial secara pribadi, (4) keterampilan dalam mengambil keputusan yang benar dan (5) keyakinan dalam menyusun rencana finansial dengan benar untuk kesejahteraan di masa mendatang.

Indikator literasi finansial di sekolah berdasarkan Materi Pendukung Literasi Finansial yang diterbitkan oleh Kementerian Pendidikan dan Kebudayaan terdiri dari tiga basis yaitu basis kelas, basis budaya sekolah, dan basis masyarakat. Basis kelas dengan 3 indikator yaitu: (1) jumlah pelatihan yang diikuti oleh kepala sekolah, guru, dan administrasi sekolah sebagai bentuk penguatan fasilitator, (2) intensitas penggunaan dan pengaplikasian literasi finansial selama kegiatan pembelajaran dan (3) dan nilai literasi finansial berlandaskan OJK atau lembaga lainnya. Basis budaya sekolah dengan tujuh indikator yaitu : (1) jumlah dan ragam buku serta alat peraga berdasarkan literasi finansial, (2) intensitas 
peminjaman buku literasi finansial oleh siswa, (3) jumlah aktivitas sebagai bentuk penguatan literasi finansial, (4) adanya kebijakan sekolah tentang penerapan nilai literasi finansial, (5) jumlah penyediaan informasi tentang literasi finansial, (6) ketersediaan situs dalam jaringan dan luar jaringan yang berkaitan dengan literasi finansial, dan (7) terdapat bank sekolah atau koperasi siswa yang berjalan aktif. Basis masyarakat dengan dua indikator yaitu: (1) ketersediaan alat dan media penunjang yang dapat menguatkan literasi finansial di sekolah dan (2) keikutsertaan orang tua dan komunitas masyarakat dalam memajukan literasi finansial di sekolah.

Fokus dalam penelitian ini adalah bagaimana gerakan literasi finansial di SMA Kabupaten Kubu Raya Kalimantan Barat? Adapun sub fokus penelitian yaitu: 1) Apakah terdapat pengembangan literasi keuangan di sekolah pada basis kelas? 2) Apakah terdapat pengembangan literasi keuangan di sekolah pada basis budaya sekolah? 3) Apakah terdapat pengembangan literasi keuangan di sekolah pada basis masyarakat? Tujuan dari pelaksanaan penelitian ini yaitu untuk mengetahui bagaimana gerakan literasi finanasial di SMA Kabupaten Kubu Raya Kalimantan Barat.

\section{Metode}

Metode yang digunakan dalam penelitian ini adalah metode deskriptif dengan bentuk survei. Pelaksanaan penelitian bertempat di SMA Kabupaten Kubu Raya Kalimantan Barat dengan subjek penelitiannya adalah guru mata pelajaran ekonomi. Teknik pengumpulan data kualitatif adalah dengan wawancara secara langsung dan dengan isian dari google form, observasi dan studi dokumentasi. Pelaksanaan analisis data dengan prosedur Analysis Interactive Model dari Miles dan Huberman, dengan langkah langkah analisis data yaitu mengumpulkan data, mereduksi data, menyajikan data dan menyimpulkan atau verifikasi.

Pemeriksaan keabsahaan data dilakukan sesuai kaidah penelitian kualitatif supaya data yang diperoleh valid dan reliabel. Teknik pemeriksaan keabsahan data dilakukan dengan triangulasi dan perpanjangan partisipan. Triangulasi yang dipilih untuk digunakan adalah triangulasi sumber dan triangulasi metode. Triangulasi sumber ditempuh dengan melakukan perbandingan data yang diterima dari berbagai sumber. Sedangkan triangulasi metode dilakukan dengan melakukan perbandingan data yang sudah dikumpulkan melalui wawancara, hasil observasi dan dokumentasi. Perpanjangan partisipan digunakan peneliti guna melengkapi informasi yang bersumber dari semua wilayah penelitian, sehingga dapat diperoleh data yang dianggap lengkap sesuai dengan sub fokus penelitian dan dapat ditarik kesimpulan

\section{Hasil dan pembahasan}

\section{Hasil Penelitian}

Hasil penelitian mengenai gerakan literasi finansial di SMA Kabupaten Kubu Raya Kalimantan Barat dengan indikator literasi finansial di sekolah pada basis kelas, basis budaya sekolah dan basis masyarakat sebagaimana pada tabel 1 berikut.

Tabel 1. Hasil Penelitian

\begin{tabular}{|c|c|}
\hline Indikator Literasi Finansial di Sekolah & Hasil Penelitian \\
\hline $\begin{array}{l}\text { Basis Kelas: } \\
\text { • Jumlah kegiatan pelatihan literasi } \\
\text { finansial }\end{array}$ & $\begin{array}{l}\text { - Belum pernah ada pelatihan literasi finansial } \\
\text { yang diikuti oleh kepala sekolah, guru, dan } \\
\text { administrasi sekolah sebagai bentuk } \\
\text { penguatan fasilitator sekolah }\end{array}$ \\
\hline $\begin{array}{l}\text { - Intensitas penggunaan dan } \\
\text { pengaplikasian literasi finansial selama } \\
\text { kegiatan pembelajaran }\end{array}$ & $\begin{array}{l}\text { - Penggunaan dan pengaplikasian literasi } \\
\text { finansial selama kegiatan pembelajaran hanya } \\
\text { dilaksanakan pada pembelajaran ekonomi } \\
\text { sesuai silabus mata pelajaran }\end{array}$ \\
\hline $\begin{array}{l}\text { - Nilai literasi finansial berlandaskan OJK } \\
\text { dan lembaga lainnya }\end{array}$ & $\begin{array}{l}\text { - Belum ada penerapan nilai literasi finansial } \\
\text { berlandaskan OJK dan lembaga lainnya }\end{array}$ \\
\hline
\end{tabular}




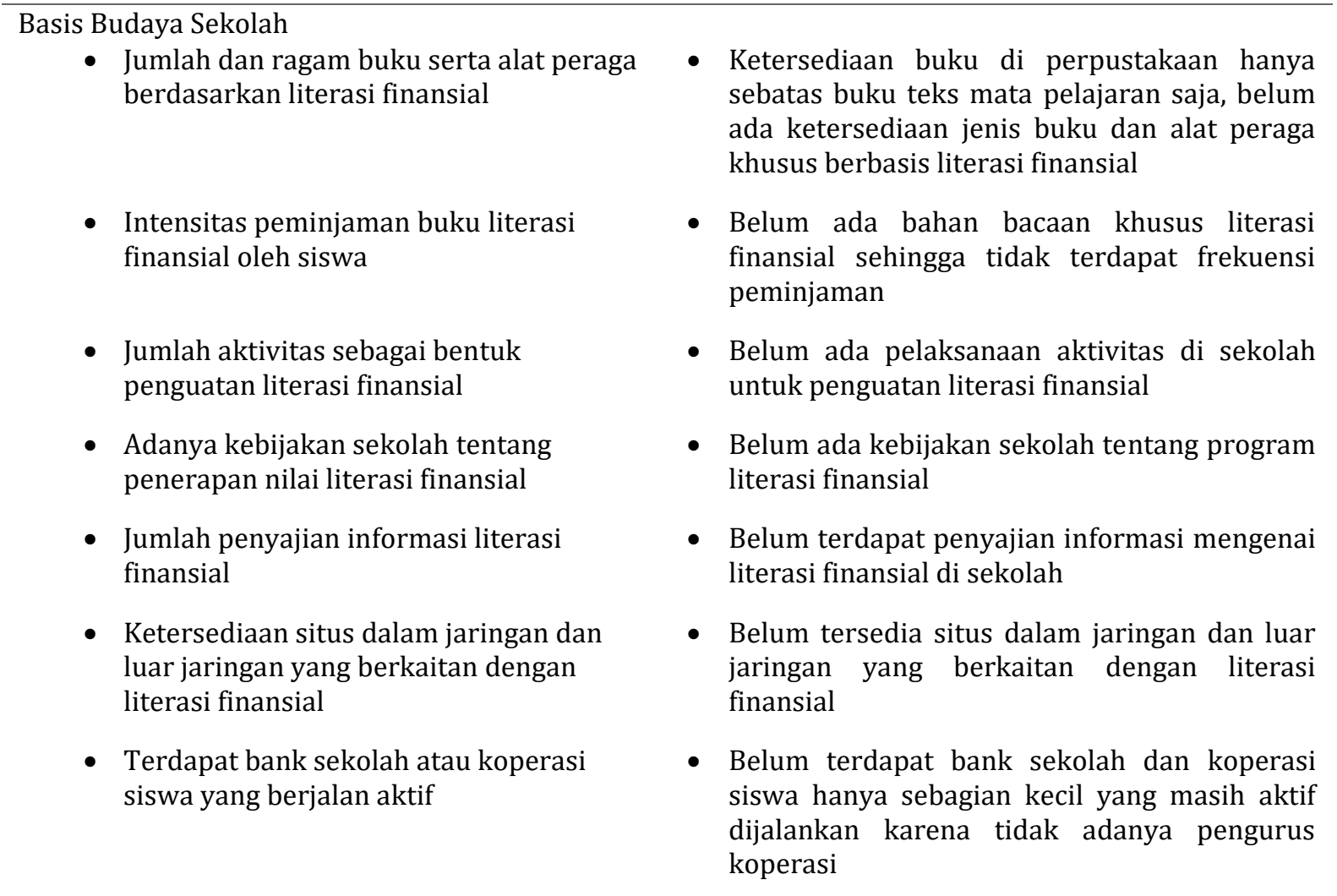

Basis Masyarakat

- Ketersediaan alat dan media penunjang yang dapat menguatkan literasi finansial di sekolah

- Keikutsertaan orang tua dan komunitas masyarakat dalam memajukan literasi finansial di sekolah
- Belum tersedia alat dan media penunjang yang dapat menguatkan literasi finansial di sekolah

- Belum ada keikutsertaan orang tua dan komunitas masyarakat dalam memajukan literasi finansial di lingkungan sekolah

\section{Pembahasan}

\section{Jumlah pelatihan yang diikuti oleh kepala sekolah, guru, dan administrasi sekolah.}

Berdasarkan hasil penelitian kepala sekolah, guru maupun tenaga administrasi belum pernah mendapat pelatihan tentang literasi finansial baik yang dilakukan oleh OJK maupun lembaga lainnya. Bahkan berdasarkan temuan di lapangan, masih terdapat guru ekonomi yang masih belum memahami konsep literasi finansial. Materi materi yang masuk dalam ruang lingkup literasi finansial diajarkan berdasarkan silabus mata pelajaran saja yaitu pada mata pelajaran ekonomi di kelas X dan di kelas XI. Selain itu tidak ada pemberian pembelajaran ataupun ekstrakurikuler yang secara langsung dikhususkan pada penguatan literasi finansial siswa.

Pelatihan bagi kepala sekolah, guru, maupun tenaga administrasi merupakan komponen penting dalam meningkatkan literasi finansial siswa. Kepala sekolah yang telah mengikuti pelatihan akan dapat membuat berbagai kebijakan budaya literasi finansial di sekolah. Sementara guru yang telah dilatih diharapakan dapat memperkaya penyajian informasi khususnya literasi finansial pada setiap mata pelajaran yang diampu. Hal ini sangat sesuai dengan hasil kegiatan pengabdian Pranoto et al., (2020) menyatakan perlu adanya upaya untuk mengintegrasikan pendidikan literasi keuangan pada Kurikulum sekolah. Karena sekolah dapat menjangkau semua anak, termasuk mereka yang memiliki kesempatan kecil untuk mengenal literasi keuangan dari luar sekolah. Selain itu, lingkungan sekolah memungkinkan pendidikan keuangan dapat diintegrasikan ke topik lain, seperti matematika, agama dsb. Pendidikan keuangan di tingkat sekolah dasar dan menengah mempunyai dampak yang baik terhadap peningkatan kompetensi keuangan siswa.

Berdasarkan buku Gerakan Literasi Finansial, pelatihan bagi guru bukan hanya diberikan kepada guru mata pelajaran ekonomi saja akan tetapi guru mata pelajaran yang lain juga dapat diberikan pelatihan sebagai bentuk penguatan fasilitator. Pelatihan ini diharapkan dapat memberikan keterampilan bagi guru 
dalam membuat permainan edukatif tentang literasi finansial dan memperluas penyampaian informasi dalam setiap mata pelajaran yang diberikan kepada siswa. Selain guru, pelatihan juga dapat diberikan kepada tenaga kependidikan sekolah agar memiliki keterampilan mengelola finansial sekolah. Hasil penelitian yang menyimpulkan bahwa belum pernah diadakan pelatihan bagi kepala sekolah, guru, maupun tenaga kependidikan menyebabkan belum adanya kebijakan atau program untuk peningkatan literasi finansial bagi siswa.

\section{Intensitas penggunaan dan pengaplikasian literasi finansial selama kegiatan pembelajaran.}

Ruang lingkup literasi keuangan terdiri dari 6 materi pokok yaitu: (1) pengertian transaksi ekonomi dan beragam jenis praktiknya, (2) pengenalan sumber daya ekonomi, (3) pengenalan konsep belanja sebagai pemenuhan kebutuhan dasar, (4) pengenalan konsep menyimpan dalam terminologi tradisional dan modern, (5) pengenalan konsep berbagi dengan berbasis pada kearifan lokal, ajaran agama, dan negara, dan (6) pengenalan konsep mengenai praktik tidak baik dan kejahatan finansial. Materi materi pokok tersebut telah diajarkan oleh guru ekonomi karena materi tersebut sudah terdapat dalam silabus kelas X dan kelas XI. Guru mengajar sesuai kompensi dasar dengan materi materi yang sudah tertera dalam silabus. Belum ada intensitas sama sekali baik dalam hal pemanfaatan maupun penerapan literasi finansial dalam kegiatan pembelajaran pada mata pelajaran lainnya. Penerapan literasi finansial di sekolah khususnya dalam kegiatan pembelajaran seharusnya dapat meningkatkan pengetahuan dan keterampilan siswa dalam mengelola keuangannya. Hal ini sesuai dengan kesimpulan hasil penelitian Laila \& Hadi (2019) menyatakan pendidikan literasi keuangan dapat membangun sikap aktif siswa untuk dapat terlibat dalam aktivitas menghasilkan suatu barang dan memberikan motivasi kepada siswa agar senang menabung.

Otoritas Jasa Keuangan pada tahun 2017 menerbitkan sebuah buku dengan judul Mengenal Otoritas Jasa Keuangan dan Industri Jasa Keuangan Kelas X sebagai bentuk upaya peningkatan literasi finansial siswa SMA/MA atau sederajat. Buku tersebut memuat berbagai teori dan konsep yang dapat membantu siswa memiliki pengetahuan mengenai fungsi dan tujuan dari terbentuknya Otoritas Jasa Keuangan. Selain itu buku tersebut juga menjelaskan secara jelas tentang produk dan jasa keuangan yang ada (OJK, 2017). Namun, buku ini belum digunakan oleh guru pengampu mata pelajaran ekonomi sebagai buku tambahan, guru ekonomi hanya memberikan materi tentang Otoritas Jasa Keuangan pada pembelajaran ekonomi di kelas X pada kompetensi dasar 3.5 Mendeskripsikan lembaga jasa keuangan dalam perekonomian dengan rujukan buku paket pelajaran.

\section{Nilai literasi finansial berlandaskan OJK dan lembaga lainnya.}

Berdasarkan hasil penelitian diketahui bahwa belum ada nilai literasi finansial berlandaskan OJK atau lembaga lain yang diterapkan oleh sekolah. Hal ini disebabkan karena di sekolah belum ada gerakan pembangunan literasi finansial, belum adanya sosialisasi dan pelatihan yang diterima oleh pihak sekolah juga menjadi penyebab minimnya pengetahuan tentang bagaimana strategi yang seharusnya ada dalam gerakan literasi finansial di sekolah.

\section{Jumlah dan ragam buku serta alat peraga berdasarkan literasi finansial.}

Berdasarkan hasil penelitian, belum terdapat alat peraga, permainan edukatif, informasi belajar, dan program menulis buku berbasis literasi finansial di SMA Kabupaten Kubu Raya Kalimantan Barat. Ketersediaan buku pada perpustakaan atau ruang baca hanya sebatas buku teks mata pelajaran ekonomi dan pendukung misalnya buku kamus ekonomi. Didalam buku teks ini sudah terdapat beragam penjelasan pendukung ruang lingkup materi literasi keuangan. Tetapi buku pendukung khusus dan alat peraga berbasis literasi finansial belum dimiliki. Selain tidak ada ketersediaan buku khusus literasi keuangan, juga belum terdapat informasi dan sumber belajar baik daring maupun luring.

Guru ekonomi juga belum mengetahui dan belum pernah memiliki buku panduan baik yang diterbitkan oleh kementerian Pendidikan dan Kebudayaan maupun Otoritas Jasa Keuangan. Minimnya referensi dan akses tentang literasi finansial menyebabkan tidak adanya buku penunjang khusus yang disediakan sehingga siswa memiliki pengetahuan yang tidak luas tentang apa itu literasi finansial. Siswa hanya mengetahui materi materi dalam mata pelajaran ekonomi saja, walaupu materi materi tersebut sudah mereka dapatkan saat pembelajaran namun tidak mengarah langsung pada gerakan literasi finansial sekolah.

\section{Intensitas peminjaman buku literasi finansial oleh siswa.}

Berdasarkan hasil penelitian, di sekolah tidak tersedia buku atau referensi khusus tentang literasi finansial. Buku yang disediakan oleh sekolah hanya berupa buku paket mata pelajaran ekonomi serta beberapa judul kamus ekonomi saja. Pada beberapa sekolah siswa diberikan kewajiban untuk meminjam buku teks ekonomi yang tersedia di ruang baca, namun ada juga sekolah dengan keterbatasan buku teks tidak mewajibkan siswa untuk meminjam buku yang tersedia di perpustakaan atau ruang baca sekolah. 
Peminjaman buku pelajaran ini sesuai dengan kebijakan sekolah masing masing, apabila buku pelajaran tersedia lengkap maka siswa diwajibkan untuk meminjam buku pelajaran di perpustakaan.

\section{Jumlah aktivitas sebagai bentuk penguatan literasi finansial.}

Berdasarkan hasil penelitian, SMA di Kabupaten Kubu Raya Kalimantan Barat belum secara optimal melaksanakan kegiatan pengembangan akses sumber belajar berkualitas yang berkaitan dengan literasi finansial. Kegiatan sosialisasi atau tabungan khusus bagi pelajar yang diberikan oleh Bank juga tidak merata dilakukan pada semua sekolah yang ada karena keterbatasan akses atau lokasi sekolah yang terlalu jauh. Belum ada pengembangan sarana penunjang lingkungan yang literat finansial dikarenakan belum adanya fasilitas khusus literasi finansial, tidak ada laboratorium finansial yang dapat mendukung penguatan literasi finansial siswa, belum optimal perpustakaan dalam penyediaan buku khusus literasi finansial maupun kegiatan lainnya yang berkaitan dengan penguatan literasi finansial siswa di sekolah.

Hal tersebut dikarenakan belum ada sosialisasi yang diterima oleh pihak sekolah mengenai kebijakan gerakan literasi finansial yang harus dilakukan. Selain itu pihak sekolah juga belum menerima pelatihan baik untuk kepala sekolah, guru maupun tenaga kependidikan yang berkaitan dengan literasi finansial. Tidak adanya bantuan berupa fasilitas bagi sekolah juga menjadi penyebab tidak adanya kegiatan atau akses bermutu yang dapat menciptakan lingkungan sekolat yang literat finansial.

\section{Adanya kebijakan sekolah tentang penerapan nilai literasi finansial.}

Berdasarkan hasil penelitian di SMA Kabupaten Kubu Raya Kalimantan Barat, sekolah belum memiliki kebijakan apapun yang berkaitan dengan literasi finansial. Tidak ada kebijakan baik dari segi penyusunan kurikulum, penyediaan bahan dan materi, sarana, maupun kegiatan sekolah yang bertujuan untuk mengembangkan nilai literasi finansial. Sekolah merupakan lembaga pendidikan yang mempunyai peran sangat penting untuk dapat menumbuhkan nilai nilai pendidikan literasi finansial, karena disanalah anak akan mendapat banyak pengalaman belajar. Di sekolah sangat efektif bagi guru dalam mengajarkan nilai nilai pendidikan literasi keuangan pada siswanya. Dalam penerapannya, pihak sekolah perlu melakukan langkah yang komprehensif yaitu dimulai dari penyusunan kurikulum, pembuatan bahan dan materi pendukung, penyediaan guru yang berkompeten dengan tujuan agar penerapan literasi finansial itu dapat berjalan lancar. Namun kenyataannya penerapan pendidikan literasi keuangan di sekolah masih belum dijalankan dengan optimal (Rapih, 2016)

\section{Jumlah penyediaan informasi tentang literasi finansial.}

Berdasarkan hasil penelitian, penyediaan informasi literasi finansial secara khusus tidak pernah dilakukan. Guru mata pelajaran ekonomi hanya memberikan pengajaran sesuai dengan silabus mata pelajaran ekonomi saja. Dalam silabus ini, terdapat materi materi dalam beberapa kompetensi dasar di kelas X dan kelas XI yang berkaitan dengan ruang lingkup literasi keuangan sesuai dengan Gerakan Literasi Finansial yang diterbitkan oleh Kementerian Pendidikan dan Kebudayaan tahun 2017.

Beragam informasi tentang literasi finansial sebenarnya sangat mudah diakses melalui jaringan internet. Guru dapat memberikan arahan kepada siswa untuk dapat membaca materi mengenai otoritas jasa keuangan dan industri jasa keuangan untuk kelas X yang dapat diakses dan diunduh secara gratis di internet. Namun pada kenyataannya, guru ekonomi saja masih belum pernah mengakses buku materi tersebut sehingga infromasi tentang literasi finansial yang diterima siswa sangat terbatas hanya pada buku paket mata pelajaran saja.

\section{Ketersediaan situs dalam jaringan dan luar jaringan yang berkaitan dengan literasi finansial.}

Berdasarkan hasil penelitian, guru maupun sekolah tidak memiliki atau menyediakan akses situs dalam jaringan maupun luar jaringan yang berhubungan dengan literasi finansial. Guru maupun sekolah belum pernah mengetahui dan memiliki referensi apapun yang berkaitan dengan literasi keuangan baik yang diterbitkan oleh kementerian Pendidikan dan Kebudayaan maupun Otoritas Jasa Keuangan. Perkembangan teknologi seharusnya dapat memudahkan setiap orang untuk dapat mengakses apa saja melalui internet. Ketersediaan bahan dan materi apapun bisa dengan sangat mudah didapat. Otoritas Jasa Keuangan melalui website resminya memberikan fasilitas yang terbuka bagi masyarakat untuk dapat mengakses informasi dan peraturan serta hasil riset mengenai jasa serta produk keuangan yang ada di Indonesia. Selain itu, referensi berupa bahan atau materi tetantang literasi finansial juga banyak diterbitkan oleh berbagai sumber. Seharusnya kemudahan akses luring dapat membantu guru maupun siswa dalam meningkatkan literasi finansial.

\section{Terdapat bank sekolah atau koperasi siswa yang berjalan aktif.}

Berdasarkan hasil penelitian, SMA Kabupaten Kubu RayaKalimantan Barat tidak memiliki bank sekolah atau bank mini yang disediakan bagi siswa. Sementara koperasi siswa, hanya sebagian kecil sekolah 
yang siswanya aktif dalam mengelola koperasi karena tidak ada yang mau menjadi pengurus jalannya koperasi siswa tersebut. Di sekolah hanya memiliki koperasi pegawai yang dianggotai oleh guru dan tenaga kependidikan setiap sekolah.

Lembaga keuangan sekolah berupa bank sekolah atau bank mini memiliki pengaruh signifikan terhadap motivasi siswa untuk menabung. Kondisi ini sesuai dengan hasil penelitian Mubarak et al., (2017) yang menyimpulkan bahwa dengan adanya bank mini siswa jadi mempunyai tabungan dan menjadi gemar menabung sebagian dari uang yang mereka miliki. Siswa yang menggunakan fasilitas bank mini di sekolah mempunyai keterampilan dalam mengatur keuangan dengan baik. Adanya fasilitas bank mini juga dapat membentuk kebiasaan siswa untuk dapat hidup hemat dengan mempraktekkan teori ekonomi sejak di bangku sekolah.

Sementara koperasi sekolah memiliki peran sebagai laboratorium belajar ekonomi meliputi : 1) menyediakan keperluan siswa di sekolah, 2) membangun sikap tanggung jawab, kemandirian, kejujuran, dan mengajarkan siswa berorganisasi, (3) mengembangkan wawasan ekonomi siswa (Witjaksono et al., 2017). Lembaga keuangan sekolah merupakan salah satu bentuk gerakan yang diharapkan dapat memberikan pengetahuan dan keterampilan bagi siswa dalam mengelola keuangan pribadinya sehingga akan dapat berdampak pada keuangannya di masa mendatang.

\section{Ketersediaan alat dan media penunjang yang dapat menguatkan literasi finansial di sekolah.}

Berdasarkan hasil penelitian, tidak terdapat alat dan media penunjang yang dapat menguatkan literasi finansial di sekolah. Hal ini dikarenakan sekolah belum mempunyai program apapun sebagai gerakan penguatan literasi finansial pada siswa. Alat dan media penunjang merupakan sesuatu yang penting dalam upaya menciptakan lingkungan yang literat finansial. Alat dan media yang dapat disiapkan oleh sekolah dapat berupa celengan, video edukatif serta alat pendukung lainnya.

\section{Keikutsertaan orang tua dan komunitas masyarakat dalam memajukan literasi finansial.}

Berdasarkan hasil penelitian, SMA di Kabupaten Kubu Raya Kalimantan Barat belum pernah mengadakan kegiatan yang melibatkan publik baik dari orang tua, komunitas masyarakat maupun lembaga luar lainnya dalam mengembangkan literasi finansial di sekolah. Hal ini dikarenakan belum ada kebijakan serta program kerja sekolah untuk penguatan literasi finansial di lingkungan sekolah yang melibatkan masyarakat.

Peningkatan pelibatan publik sangat penting untuk membangun suasana dan budaya literasi di lingkungan sekolah. Kegiatan dapat berupa sharring session, bulan literasi finansial, project based learning dan kegiatan lain yang melibatkan lembaga keuangan atau masyarakat. Namun kenyataan di lapangan kegiatan kegiatan ini belum pernah dilakukan di lingkungan sekolah.

\section{Simpulan dan saran}

\section{Simpulan}

Sesuai hasil penelitian dan pembahasan diperoleh kesimpulan bahwa belum terdapat gerakan literasi finansial di sekolah baik pada basis kelas, basis budaya sekolah dan basis masyarakat di SMA Kabupaten Kubu Raya Kalimantan Barat.

\section{Saran}

Saran yang dapat diberikan adalah kepala sekolah, guru, maupun tenaga administrasi hendaknya diberikan pelatihan sebagai bentuk penguatan kapasitas fasilitator agar setiap sekolah dapat merancang dan melaksanakan gerakan literasi finansial. Pemerintah diharapkan dapat menyediakan atau memfasilitasi bahan, materi maupun pendanaan bagi sekolah agar sekolah dapat membuat kegiatan kegiatan yang dapat meningkatkan literasi finansial siswa. MGMP sebagai organisasi musyawarah guru mata pelajaran ekonomi diharapkan dapat dijadikan sebagai tempat berdiskusi mengenai pendidikan literasi finansial di sekolah khususnya pada mata pelajaran ekonomi.

\section{Daftar Rujukan}

Fianto, F., Prismayani, R., Wijaya, N. I., Miftahussururi, Hanifah, N., Nento, M. N., Akbari, Q. S., \& Adryansyah, N. (2017). Gerakan Literasi Finansial.

Laila, V., \& Hadi, S. (2019). Pelaksanaan Pendidikan Literasi Finansial pada Siswa Sekolah Dasar. Jurnal Pendidikan: Teori, Penelitian, Dan Pengembangan, 2006, 1491-1495.

Lusardi, A. (2019). Financial literacy and the need for financial education: evidence and implications. Swiss 
Journal of Economics and Statistics, 155(1), 1. https://doi.org/10.1186/s41937-019-0027-5

Lusardi, A., Michaud, P. C., \& Mitchell, O. S. (2017). Optimal financial knowledge and wealth inequality. Journal of Political Economy, 125(2), 431-477. https://doi.org/10.1086/690950

Mubarak, Z., Wahjoedi, W., \& Mardono, M. (2017). Pengaruh Tingkat Pengetahuan Ilmu Ekonomi dan Pemanfaatan Bank Mini Sekolah terhadap Minat Menabung Siswa Kelas XI IPS SMA Negeri 2 Malang. Jurnal Pendidikan Ekonomi, 10(1), 1-14. https://doi.org/10.17977/UM014v10i12017p001

OJK. (2017). Mengenal OJK dan IJK Tingkat SMA i Mengenal Otoritas Jasa Keuangan dan Industri Jasa Keuangan.

Pranoto, P., Fauzi, R. D., Kustini, E., Maduningtias, L., \& Yuangga, K. D. (2020). Literasi Keuangan (Financial Literacy) untuk Siswa SMK Sasmita Jaya. BAKTIMAS : Jurnal Pengabdian Pada Masyarakat, 2(2), 119122. https://doi.org/10.32672/btm.v2i2.2137

Rapih, S. (2016). PENDIDIKAN LITERASI KEUANGAN PADA ANAK: Mengapa dan Bagaimana? Scholaria: Jurnal Pendidikan Dan Kebudayaan, 6(2), 14. https://doi.org/10.24246/j.scholaria.2016.v6.i2.p1428

Remund, D. L. (2010). Financial literacy explicated: The case for a clearer definition in an increasingly complex economy. Journal of Consumer Affairs, 44(2), 276-295. https://doi.org/10.1111/j.17456606.2010.01169.x

Sari, E. S., \& Pujiono, S. (2017). BUDAYA LITERASI DI KALANGAN MAHASISWA FBS UNY. LITERA, 16(1), 105-113. https://doi.org/10.21831/ltr.v16i1.14254

Witjaksono, M., Universitas, P. E., \& Malang, N. (2017). Peran Keberadaan Koperasi Siswa Sebagai. Jurnal Pendidikan: Teori, Penelitian, Dan Pengembangan, 166-172. 